Інноватика у вихованні. Випуск 12. 2020.

УДК 337:338.47:001+(045)

DOI: $\underline{10.35619 / \text { iiu.v1i12.296 }}$

Короткова Ліна

кандидат педагогічних наук, директор державного навчального закладу «Запорізьке вище професійне училище моди і стилю»,

м. Запоріжжя, Україна

ORCID: 0000-0002-6635-2063

e-mail:modastil@ukr.net

\title{
ЧИННИКИ ПРОФЕСІЙНОЇ ПІДГОТОВКИ МАЙБУТНІХ ФАХІВЦІВ СФЕРИ ПОСЛУГ В УМОВАХ ОСВІТНЬО-ВИРОБНИЧОГО КЛАСТЕРА
}

Анотація. У статті обгрунтовано чинники професійної підготовки майбутніх фахівців сфери послуг в умовах освітньо-виробничого кластера. До зовнішніх чинників віднесено законодавчо-правові, економічні, соціально-демографічні, науково-технологічні фактори. Внутрішніми чинниками визначено управлінську діяльність, інформаційно-освітне середовище, професійну компетентність педагогічних працівників.

Законодавчо-правові чинники, що мають характер чинних законодавчих актів державного, регіонального, місцевого рівнів та правових норм, регулюють відносини між учасниками освітнього процесу й окреслюють перспективи їхнього подальшого розвитку. Економічні - забезпечують збалансованість співпраці між учасниками освітньо-виробничого кластера. Серед соціальнодемографічних чинників важливе місце займають соціальне замовлення, статево-вікова структура населення країни, зайнятість працездатного населення. Науково-технологічні чинники визначають структуру професійної підготовки, виникнення іiї нових форм, видів й спеціалізації.

Управлінська діяльність в умовах кластерної структури визначається інтеграцією суб'єктів, пов'язаних освітньо-виробничим циклом та передбачає задоволення здобувачів освіти й представників підприємств завдяки впровадженню єдиної для стратегії професійної підготовки та розвитку кадрового потенціалу. Інформаційно-освітне середовище створено для забезпечення умов ефективної взасмодії учасників освітньо-виробничого кластера, реалізації спільних проєктів та ініціатив щодо розвитку професійної компетентності майбутніх фахівців сфери послуг. В умовах кластерного об'єднання підвищення рівня професійної компетентності педагогічних працівників має важливе значення для професійної підготовки майбутніх фахівців й оцінюється за розробленими комплексними критеріями.

Ключові слова: зовнішні чинники, внутрішні чинники, професійна підготовка, майбутні фахівці сфери послуг, освітньо-виробничий кластер.

Постановка проблеми. В умовах глобалізації та інформатизації сучасного світу професійна (професійно-технічна) освіта (далі - П(ПТ)О) безпосередньо впливає на соціально-економічний рівень країни, забезпечуючи ії національну безпеку, суспільний прогрес та стабільний розвиток. Нові виклики часу вимагають від системи професійної підготовки майбутніх фахівців, зокрема сфери послуг, розширення освітніх функцій, посилення іiі інноваційної 
спрямованості; раціональної і збалансованої співпраці із представниками влади, науки i бізнесу, що забезпечується формуванням в регіонах освітньовиробничих кластерів (далі-ОВК). Кластеризація професійної підготовки майбутніх фахівців сфери послуг передбачає іï модернізацію, удосконалення управління, розширення джерел фінансування, інтеграцію виробничих процесів, професіоналізацію кадрів, формування в регіоні ринку конкурентоспроможних фахівців, забезпечення працевлаштування випускників закладів П(ПТ)О. Важливого значення при цьому набуває моделювання педагогічної системи професійної підготовки майбутніх фахівців сфери послуг в умовах ОВК, необхідною передумовою якого $\epsilon$ аналіз чинників, що визначають особливості названої системи.

Аналіз останніх досліджень 3 проблеми. Аналіз сучасної психологопедагогічної літератури засвідчує різні підходи до класифікації дефініції «чинник», розуміння іiї сутності, змісту та структурування. Переважна більшість вітчизняних й зарубіжних дослідників вважають, що на якість професійної підготовки майбутніх фахівців сфери послуг в умовах ОВК впливає сукупність чинників, зокрема індивідуально-типологічних і дидактичних (Г. Романова) (Романова, 2003); забезпечення якості змісту освіти; покращення методів технологій навчання (Л. Лосєва) (Лосєва, 2011); вхідних, внутрішніх й вихідних (В. Сафонова) (Сафонова, 2011); професійних й педагогічних (М. Михнюк) (Михнюк, 2015); соціально-економічних, організаційно-педагогічних, особистісних (I. Андрощук) (Андрощук, 2017); суб'єктивних та об’єктивних (О. Карпюк) та ін.

Проте, як свідчить проведений аналіз наукової літератури, проблема визначення чинників, які впливають на процес професійної підготовки майбутніх фахівців сфери послуг в умовах ОВК, $є$ недостатньо розкритою в працях науковців, що обумовлює актуальність і необхідність теоретикопрактичного дослідження цього питання.

Мета статті полягає в обгрунтуванні основних чинників професійної підготовки майбутніх фахівців сфери послуг в умовах ОВК, що здатні покращити процес формування їхньої професійної компетентності.

Виклад основного матеріалу дослідження. Узагальнюючи результати досліджень і враховуючи специфіку сфери послуг, особливості функціонування ОВК, ми розглядаємо чинники професійної підготовки майбутніх фахівців сфери послуг в умовах ОВК як зовнішні (законодавчо-правові, економічні, соціально-демографічні, науково-технологічні) й внутрішні (управлінська діяльність, інформаційно-освітне середовище, професійна компетентність педагогічних працівників) інструменти впливу на освітній процес, його зміст, структуру, якісний рівень.

До законодавчо-правових чинників нами віднесено чинні законодавчі акти державного, регіонального, місцевого рівнів та правові норми, що визначають межі правового поля, регулюють відносини між учасниками освітнього процесу й окреслюють перспективи їхнього розвитку. Пріоритетні напрями та основні шляхи розвитку професійної підготовки визначають доктрини, програми, концепції. Правові, організаційні, фінансові та інші засади функціонування системи формування професійної компетентності майбутніх фахівців закріплюються законами, договорами, наказами і розпорядженнями Президента України, Міністерства освіти і науки, регіональних (місцевих) органів 
виконавчої влади; постановами Верховної Ради та Кабінету Міністрів України (Кремень, 2016).

Вплив економічних чинників розглядається на глобальному рівні (урахування всесвітніх тенденцій суспільного розвитку), державному (стабільність політичної ситуації в країні) й регіональному (збалансованість бюджетно-фінансової системи, наявність трудового потенціалу, інтелектуального капіталу). Відповідно, професійна підготовка майбутніх фахівців сфери послуг в умовах ОВК зорієнтована на парадигму раціональної і збалансованої співпраці між учасниками кластерного об'єднання, посилення інноваційності освітнього процесу.

Серед соціально-демографічних чинників важливе місце займають: соціальне замовлення; статево-вікова структура населення країни, динаміка його відтворення; зайнятість незайнятого населення; освітні потреби особистості, іiі задоволеність в соціалізації, самовизначенні, підвищенні матеріального добробуту й рівня професійної майстерності.

Безпосередньо впливають на якість професійної підготовки майбутніх фахівців сфери послуг в умовах ОВК науково-технологічні чинники, що визначають творчий потенціал здобувачів освіти, їхню професійну гнучкість, адаптивність, здатність вирішувати проблеми, аналізувати ситуації, логічно мислити, пристосовуватися до змін в економічній кон'юнктурі, відповідати за прийняті рішення і наслідки своєї професійної діяльності.

До чинників внутрішнього впливу віднесено: управлінську діяльність; створення єдиного інформаційно-освітнього середовища; професійну компетентність педагогічних працівників.

Управлінська діяльність як чинник внутрішнього впливу на якість професійної підготовки майбутніх фахівців сфери послуг в умовах ОВК представляє собою багатовимірний процес, що передбачає задоволення запитів й потреб всіх суб'єктів, пов'язаних освітньо-виробничим циклом завдяки впровадженню єдиної для закладів освіти і підприємств сфери послуг регіону стратегії професійної підготовки та розвитку кадрового потенціалу 3 відповідними методами і формами управління (Калініна, 2004). Ключовими характеристиками управління в умовах ОВК є орієнтація на кінцевий результат; можливість швидкого й адекватного реагування на вплив зовнішніх і внутрішніх факторів; зацікавленість кожного учасника кластерного об'єднання у підвищенні ефективності як своєї роботи, так і спільного продукту діяльності; впровадження моніторингу якості всіх процесів, що забезпечують необхідний рівень професійної компетентності.

Управлінська діяльність в умовах ОВК передбачає застосування традиційних (планування, організація, стимулювання, контроль) та інноваційних управлінських функцій (координуюча, прогнозуюча, консолідуюча, реорганізуюча), що поєднані між собою процесами комунікації. Отже, координуюча функція передбачає чіткий розподіл повноважень між учасниками кластерної структури, узгоджену взаємодію соціальної інфраструктури й виробництва з урахуванням специфіки регіону та інтересів суб'єктів освітнього процесу, а також перехід від традиційних форм управління на рівень самоуправління. Прогностична функція обумовлює оновлення форм управління відповідно до соціального замовлення суспільства шляхом спільного вирішення освітніх i виробничих завдань, що сприяє випереджальній практиці впровадження новітніх форм, методів, інноваційних педагогічних і виробничих 
технологій, спрямованих на підвищення рівня професійної підготовки майбутніх фахівців сфери послуг. Консолідуюча функція спрямована на об'єднання учасників ОВК в єдину систему із збереженням своєї цілісності як самостійної організації; орієнтує державних і приватних партнерів на загальні цінності та інтереси. Реорганізуюча функція передбачає коригування і оновлення процесу управління 3 урахуванням вимог суспільства, ринкової економіки, освіти і науки; особистісне і професійне становлення майбутніх фахівців, формування в них комплексу компетентностей, необхідних для подальшої освіти, працевлаштування, досягнення індивідуальних інтересів i професійного зростання.

Для практичної реалізації цих функцій в умовах кластерної структури створено постійно діючі Координаційні органи (галузевий, науково-освітній, територіальний), діяльність яких спрямована на формування структурноорганізаційного складу системи управління професійною підготовкою майбутніх фахівців сфери послуг. До складу галузевого координаційного органу управління входять представники підприємств і організацій регіону за галузевим спрямуванням, до функцій яких віднесено забезпечення якості професійної підготовки здобувачів освіти відповідно до вимог ринку праці; до територіального - представники виконавчої влади, основними завданнями яких $\epsilon$ нормативно-правове забезпечення управління професійною підготовкою майбутніх фахівців в умовах ОВК; до науково-освітнього-члени науководослідних установ і закладів П(ПТ)О, які відповідають за впровадження нових форм та технологій державно-приватного партнерства.

Важливим внутрішнім чинником професійної підготовки майбутніх фахівців сфери послуг в умовах ОВК є інформаційно-освітнє середовище, що оцінюється за такими критеріями як: визначеність, оцінюваність, структурованість, відкритість, безпечність, динамічність, соціальна комфортність, інтегративність, багатоаспектність, поліфункціональність, доступність, емоційна насиченість. Основні його властивості, зокрема фізичні (температура, освітленість, циркуляція повітря, гігієна), його цінності (відсутність дискримінації і булінгу, неконфліктність, зручність, емоційний комфорт), допустимі механізми діяльності визначено, сформульовано й оприлюднено в документах закладу освіти (Статуті, освітніх програмах, положеннях, наказах, заходах та ін.). Комфортність, відкритість інформаційно-освітнього середовища, його динамічність, безпечність для життя та здоров'я, можливість змінюватися й вдосконалюватися з урахуванням потреб замовників освітніх послуг й очікувань зацікавлених сторін передбачає можливість особистісної самореалізації суб'єктів освітнього процесу, їх індивідуального прогресу в професійному та психологічному аспектах. Комплексна оцінка якості інформаційно-освітнього середовища здійснюється шляхом системної експертизи, вимірювання, інтерв'ювання, моніторингу, внутрішнього аудиту, методами спостереження, вивчення документації, опитування, анкетування, що має на меті збереження та зміцнення здоров'я здобувачів освіти, розвитку їх пізнавальної та особистісної cфер.

Для підвищення якості професійної підготовки майбутніх фахівців сфери послуг важливого значення набуває рівень професійної компетентності педагогічних працівників. В умовах ОВК оцінювання ефективності їхньої освітньої діяльності здійснюється за єдиними комплексними критеріями 3 урахуванням сучасних світових тенденцій розвитку професійної освіти 
(Ляшенко, 2012). Методика оцінювання педагогічних працівників грунтується на таких принципах: прозорості (відкритість і чітка аргументованість показників, за якими визначається рейтинг); достовірності (отримання об'єктивної інформації на підставі сформованої системи визначених показників та вагових коефіцієнтів); доступності (зрозумілість і доступність системи оцінювання); педагогічного оптимізму (спрямованість не на штрафні санкції, а на підтримку й заохочення тих, які досягли високих здобутків у роботі); гнучкості (можливість встановлення нових пріоритетів через зміну вагових коефіцієнтів для оцінки видів освітньої діяльності).

Зазначимо, що в умовах ОВК підвищення рівня професійної компетентності педагогічних працівників набуває додаткових форм, а саме: надається можливість використовувати матеріально-технічну базу підприємств-учасників кластерного об'єднання, опрацьовувати нові технології на сучасному обладнанні, залучати до співпраці науковців, фахівців закладів вищої освіти, провідних спеціалістів підприємств регіону, представників громадських організацій тощо.

Висновки і перспективи подальших розвідок. Отже, урахування чинників професійної підготовки майбутніх фахівців сфери послуг в умовах ОВК передбачає здійснення ефективної освітньої діяльності 3 використанням інноваційних педагогічних та виробничих технологій, спрямованої на формування професійної компетентності зазначеної категорії фахівців відповідно до потреб замовників кадрів. Перспективами подальших досліджень у цьому напрямі $\epsilon$ об'єктивне визначення сучасних ідей i положень методологічних підходів, що максимально відображають вимоги суспільства й виробництва до рівня професійної компетентності випускників закладів П(ПТ)O.

\section{СПИСОК ВИКОРИСТАНИХ ДЖЕРЕЛ}

Кремень, В. (2016). Національна доповідь про стан і перспективи розвитку освіти в Україні. Київ: Педагогічна думка. 448 с.

Романова, Г. (2003). Індивідуально-типологічні та дидактичні чинники результативності самостійної роботи студентів економічних університетів. Кандидат педагогічних наук . Ін-т педагог. і психолог. проф. освіти АПН України. Київ. 21 с.

Лосева, Л. (2011). Качество подготовки специалиста в системе высшего профессионального образования как объект управления. Молодой ученый. № 6. T. 2. c. $152-155$.

Сафонова, В. (2011). Теоретичні підходи до аналізу чинників та умов впливу на якість вищої освіти. Стратегія розвитку України. № 3. С. 37-43.

Михнюк, М. (2015). Розвиток професійної культури викладачів спеціальних дисииплін будівельного профілю: монографія. Кіровоград: Імекс. 367 с.

Андрощук, I. (2004). Підготовка майбутніх учителів трудового навчання та технологій до педагогічної взаємодії у професійній діяльності: теорія $i$ методика: монографія. Хмельницький: Цюпак А. 455 с.

Калініна, Л. (2004). Теоретичні підходи до управління навчальним закладом. Директор школи. с. 6-10.

Ляшенко, О., Лукіна, Т., Булах, І., Мруга, М. (2012). Методика і технології оцінювання діяльності загальноосвітнього навчального закладу: посібник. Київ: Педагогічна думка. 160 с. 


\section{REFERENCES}

Kremen, V. (2016). Natsionalna dopovid pro stan i perspektyvy rozvytku osvity $v$ Ukraini [National report on the state and prospects of education development in Ukraine]. Kyiv: Pedahohichna dumka. 448 s. [in Ukrainian]

Romanova, H. (2003). Indyvidualno-typolohichni ta dydaktychni chynnyky rezultatyvnosti samostiynoyi roboty studentiv ekonomichnykh universytetiv [Individual-typological and didactic factors of efficiency of independent work of students of economic universities], Candidate of Pedagogical Sciences. Institute of Pedagogy and Psychology of Vocational Education of the Academy of Pedagogical Sciences of Ukraine, Kiev. 21 s. [in Ukrainian]

Loseva, L. (2011). Kachestvo podgotovki spetsialista v sisteme vysshego professional'nogo obrazovaniya kak ob'yekt upravleniya [The quality of specialist training in the system of higher professional education as an object of management]. Young scientist. No 6. Vol. 2. s. 152-155. [in Ukrainian]

Safonova, V. (2011). Teoretychni pidkhody do analizu chynnykiv ta umov vplyvu na yakist vyshchoi osvity [Theoretical approaches to the analysis of factors and conditions of influence on the quality of higher education]. Development strategy of Ukraine. No 3. s. 37-43. [in Ukrainian]

Mykhniuk, M. (2015). Rozvytok profesiinoi kultury vykladachiv spetsialnykh dystsyplin budivelnoho profiliu: monohrafiia [Development of professional culture of teachers of special disciplines of construction profile: monograph]. Kirovohrad: Imeks. 367 s. [in Ukrainian]

Androshchuk, I. (2017). Pidhotovka maibutnikh uchyteliv trudovoho navchannia ta tekhnolohii do pedahohichnoi vzaiemodii u profesiinii diialnosti: teoriia i metodyka [Preparation of future teachers of labor education and technologies for pedagogical interaction in professional activity: theory and methods]. Khmelnytskyi: Tsiupak A. 455 s. [in Ukrainian]

Kalinina, L. (2004). Teoretychni pidkhody do upravlinnia navchalnym zakladom [Theoretical approaches to the management of an educational institution]. School Director. s. 6-10. [in Ukrainian]

Liashenko, O., Lukina, T., Bulakh, I., Mruha, M. (2012). Metodyka i tekhnolohii otsiniuvannia diialnosti zahalnoosvitnoho navchalnoho zakladu: posibnyk [Methods and technologies for evaluating the activities of a secondary school: a guide]. Kyiv: Pedahohichna dumka. $160 \mathrm{~s}$. [in Ukrainian] 


\title{
FACTORS OF PROFESSIONAL TRAINING OF FUTURE SERVICE SPECIALISTS IN THE CONDITIONS OF EDUCATIONAL AND PRODUCTION CLUSTER
}

\author{
Lina Korotkova \\ $\mathrm{PhD}$ of Sciences in Education, \\ Director of the Zaporizhzhia higher vocational \\ school of fashion and style, \\ Zaporizhzhia, Ukraine \\ ORCID: 0000-0002-6635-2063 \\ e-mail:modastil@ukr.net
}

\begin{abstract}
The article substantiates the external and internal factors of professional training of future service professionals in the educational and production cluster. External factors include legal, economic, socio-demographic, scientific and technological factors. Internal factors determine the management activities, information and educational environment, professional competence of teachers.

Legislative and legal factors, which have the character of current legislative acts of the state, regional, local levels and legal norms, regulate the relations between the participants of the educational process and outline the prospects for their further development. Economic ensure a balanced cooperation between the participants of the educational and production cluster. Among the socio-demographic factors an important place is occupied by the social order, gender and age structure of the country's population, employment of the working population. Scientific and technological factors determine the structure of professional training, the emergence of its new forms, types and specialization.

Management activity in the cluster structure is determined by the integration of entities associated with the educational and production cycle, provides for the satisfaction of students and representatives of enterprises through the introduction of a single strategy for training and human resource development. The information and educational environment is created to provide conditions for effective interaction of participants of the educational and production cluster, implementation of joint projects and initiatives for the development of professional competence of future service professionals. In the conditions of cluster association, the increase of the level of professional competence of pedagogical workers is important for the professional training of future specialists and is evaluated according to the only complex criteria based on the principles: transparency; reliability; accessibility; pedagogical optimism; flexibility.
\end{abstract}

Key words: external factors, internal factors, professional training, future specialists in the field of services, educational and production cluster.

Стаття надійшла до редакиії 23. 09. 202 р. 